\title{
KAJIAN EFEKTIVITAS PROGRAM CORPORATE SOCIAL RESPONSIBILITY (CSR): STUDI KASUS PERUSAHAAN PEMBANGKIT ENERGI "Y"
}

\author{
Adityo Wicaksono ${ }^{1}$, Mahardhika Berliandaldo ${ }^{2}$, \\ Firman Tri Ajie ${ }^{1}$, Kirana Rukmayuninda Ririh $^{1 *}$ \\ ${ }^{1}$ Pusat Penelitian Kebijakan dan Manajemen Ilmu Pengetahuan, Teknologi, dan Inovasi (P2KMI), Lembaga Ilmu \\ Pengetahuan Indonesia (LIPI) \\ Jl. Jend. Gatot Subroto 10, Jakarta, Indonesia 12710 \\ ${ }^{2}$ Biro Umum (BU), Lembaga Ilmu Pengetahuan Indonesia (LIPI), \\ Jl. Jend. Gatot Subroto 10, Jakarta, Indonesia 12710
}

(Received: August 31, 2020/ Accepted: January 5, 2021)

\begin{abstract}
Abstrak
Perusahaan pembangkit energi dikenal dengan operasi bisnisnya yang menimbulkan dampak negatif sosial dan lingkungan yang cukup massif. Oleh karena itu perusahaan perlu melaksanakan tindakan mitigasi untuk mereduksi dampak negatif tersebut melalui program CSR. Efektivitas program CSR penting dievaluasi untuk mengetahui apakah dapat menghadirkan dampak sosial-lingkungan positif secara signifikan atau tidak. Salah satu metode evaluasi dampak yang populer digunakan oleh lembaga non-profit di berbagai negara adalah metode Social Return on Investment (SROI). Namun masih sedikit penelitian empiris yang dilakukan untuk memberikan bukti implementasi metode ini dalam konteks evaluasi program CSR. Untuk itu, penelitian ini bertujuan untuk mengisi kesenjangan yang ada dengan memberikan bukti empiris implementatif dan modifikasi kecil pada metode SROI untuk evaluasi CSR. Lebih lanjut penelitian ini juga memberikan kontribusi praktikal dengan menyediakan gambaran bagi perusahaan pembangkit energi untuk dapat mengukur efektivitas program CSR menggunakan metode SROI. Hasil pengukuran dapat menjadi dasar optimasi program CSR perusahaan. Dalam studi kasus Perusahaan Pembangkit Energi " $Y$ ", hasil perhitungan SROI menunjukkan bahwa program CSR yang dilakukan "cukup efektif" dengan total dampak positif yang ditimbulkan sebesar Rp. 2,69 untuk tiap rupiah yang diinvestasikan. Namun, Perusahaan " $Y$ " cenderung banyak melakukan aktivitas yang berdampak sosial dan minim aktivitas yang berdampak positif terhadap lingkungan.
\end{abstract}

Kata kunci: Corporate Social Responsibility; Dampak Lingkungan; Dampak Sosial; Efektivitas; SROI.

\begin{abstract}
A Study of Corporate Social Responsibility (CSR) Program Effectiveness: A Case Study in Energy Company "Y". Energy companies are known for their massive impacts on the social and environmental condition. Hence, they must conduct mitigation actions for reducing the negative impacts through CSR programs. A continuous evaluation of CSR programs effectiveness is crucial to understand whether they can bring significant social-environmental returns or not. One of the most popular methods of impact evaluation utilized by non-profit organizations is Social Return on Investment (SROI). However, only a few empirical research provides evidence for the implementation of this method in the context of CSR program evaluation. Therefore, this research aims to address this hiatus by giving empirical evidence on SROI implementation and incremental modification for CSR evaluation. Furthermore, this research also provides practical contributions by depicting how an energy company can measure its CSR program utilizing SROI. The measurement result can be used as guidance for optimizing the company's CSR program. In our case

*Penulis Korespondensi. study of Power Generator Company " $Y$ ", the SROI calculation shows that the CSR program is "effective" with a total return Rp. 2.69 for each
\end{abstract}

E-mail: kirana.rukmayuninda.ririh@lipi.go.id 


\begin{abstract}
rupiah invested. However, Company " $Y$ " tend to conduct more activities for social return, rather than activities for environmental return.
\end{abstract}

Keywords: Corporate Social Responsibility; Environmental Impact; Effectiveness; Social Impact; SROI.

\section{Pendahuluan}

Menjaga keseimbangan antara kegiatan komersial, aktivitas sosial, dan menjaga kelestarian lingkungan sangatlah penting bagi keberlanjutan bisnis, terutama untuk industri pembangkitan energi. Program Corporate Social Responsibility (CSR) merupakan salah satu kewajiban yang dilakukan oleh perusahaan sebagai bentuk tanggung jawab atas operasional bisnisnya yang telah menimbulkan dampak sosial maupun lingkungan. Pelaksanaan program CSR idealnya merupakan upaya yang sungguh-sungguh dilaksanakan perusahaan untuk kebaikan sosial maupun lingkungan, tidak hanya sebagai bentuk kepatuhan terhadap peraturan yang berlaku (McWilliams, Siegel, \& Wright, 2006; McWilliams \& Siegel, 2001). Oleh karena itu, program tersebut harus direncanakan dengan baik untuk mendapatkan manfaat yang sebesar-besarnya bagi masyarakat dan lingkungan terdampak.

Operasional bisnis pembangkitan energi berbahan bakar fosil sangat beresiko menimbulkan terjadinya perubahan pada kualitas lingkungan dan perubahan sosial pada masyarakat. Pembangkit energi berbahan bakar fosil dapat menimbulkan dampak lingkungan seperti pemanasan global dan hujan asam (Harjanto, 2008). Penyebab utama dari perubahan lingkungan tersebut adalah emisi dari proses pembangkitan energi berupa polutan udara (hidrokarbon, $\mathrm{NO}_{2}, \mathrm{CO}$, dan $\mathrm{CO}_{2}$ ) (Astra, 2010). Perubahan lingkungan tersebut akan menimbulkan dampak turunan mencakup perubahan iklim yang mengakibatkan bencana alam, naiknya permukaan air laut, dan kerusakan ekosistem.

Dampak sosial yang terjadi akibat kegiatan pembangkitan energi cukup beragam, baik positif maupun negatif. Dampak positif dari kegiatan pembangkitan energi adalah modernisasi dan peningkatan ekonomi masyarakat. Sedangkan dampak negatif dari kegiatan tersebut antara lain adalah adanya gangguan kesehatan (kelainan jantung, saluran pernafasan, paru-paru, dan kulit) gangguan kenyamanan akibat kebisingan, penyimpangan sosial, dan timbulnya kecemburuan sosial antar warga (antara kelompok masyarakat yang mendapatkan manfaat dengan yang tidak mendapatkan) (Astra, 2010; Prakoso, Rostyaningsih, Sundarso, \& Maron, 2016).

Dampak negatif sosial-lingkungan dari kegiatan pembangkitan energi yang tidak direspon dan dimitigasi pada akhirnya akan berdampak buruk bagi kelangsungan bisnis energi itu sendiri. Bencana alam seperti banjir yang diakibatkan oleh kerusakan lingkungan dapat mengakibatkan berhentinya kegiatan bisnis pembangkitan. Masyarakat yang terdampak dapat melakukan unjuk rasa dan melakukan tindakan tuntutan secara hukum yang akan mengakibatkan kerugian yang signifikan bagi perusahaan. Disinilah pentingnya program CSR untuk dilaksanakan secara efektif. Dengan alokasi dana CSR, perusahaan secara bersama-sama dengan masyarakat dan lembaga swadaya masyarakat dapat bekerja-sama meminimalisir terjadinya dampak sosial-lingkungan yang terjadi.

Dalam beberapa literatur terdahulu, CSR telah banyak dikonseptualisasikan oleh banyak peneliti. Kegiatan CSR dapat dipandang sebagai investasi strategis untuk membangun reputasi dan melakukan diferensiasi terhadap pesaing (McWilliams, Siegel, \& Wright, 2006), serta menarik pelanggan yang memiliki rasa tanggung jawab sosial yang tinggi (Baron, 2001). Kegiatan tersebut dapat pula dipandang sebagai komitmen dan kewajiban moral pimpinan perusahaan terhadap para stakeholder (termasuk stakeholder non-finansial) (Donaldson \& Preston, 1995). Penelitian-penelitian terdahulu telah banyak mengupas manfaat dan pelaksanaan kegiatan CSR bagi perusahaan untuk membangun reputasi, memenangkan persaingan, menarik pelanggan, dan menjaga keberlanjutan bisnis (Baron, 2001; McWilliams, Siegel, \& Wright, 2006; Middlemiss, 2003; Piercy \& Lane, 2009); namun masih sedikit yang mengkonseptualisasikan bagaimana kegiatan tersebut dapat diukur dan dievaluasi.

Pelaksanaan kegiatan CSR di Indonesia berlandaskan pada UU No 40 tahun 2007 mengenai Perseroan Terbatas, pasal 74 ayat (1) yang berbunyi, "Perseroan yang menjalankan kegiatan usahanya di bidang dan/ atau berkaitan dengan sumber daya alam wajib melaksanakan Tanggung Jawab Sosial dan Lingkungan." Berdasarkan undang-undang tersebut, bila perusahaan tidak menjalankan kegiatan CSR, maka akan dikenakan sanksi sesuai peraturan perundang-undangan. Lebih lanjut pemerintah menerbitkan PP No. 47 Tahun 2012 sebagai peraturan pelaksana undang-undang yang berisi sembilan pasal. Pada PP No. 47/2012, pasal 4 ayat (1) disebutkan bahwa "Tanggung jawab sosial dan lingkungan dilaksanakan oleh Direksi berdasarkan rencana kerja tahunan Perseroan setelah mendapat persetujuan Dewan Komisaris atau RUPS sesuai dengan anggaran dasar Perseroan, kecuali ditentukan lain dalam peraturan perundang-undangan." Kelemahan terbesar dari kedua peraturan perundang-undangan tersebut adalah tidak mengatur persentase besaran CSR yang wajib dikeluarkan perusahaan dan tidak mewajibkan adanya evaluasi pelaksanaan kegiatan CSR. Hal ini 
menyebabkan perusahaan masih sangat leluasa untuk meminimalisir anggaran dan memanipulasi pelaksanaan kegiatan CSR.

Oleh karena itu, kajian ini berusaha menjawab permasalahan yang ada dan mengisi kesenjangan literatur melalui penguatan konseptualisasi kegiatan CSR dari segi evaluasi pelaksanaannya, serta memberikan bukti empiris proses evaluasi tersebut. Konseptualisasi evaluasi dibangun melalui studi kasus evaluasi efektivitas kegiatan CSR di perusahaan pembangkit energi ' $\mathrm{Y}$ '. Dalam studi kasus ini, tim peneliti melakukan observasi dan wawancara mendalam dengan beberapa stakeholder perusahaan ' $Y$ '. Hasil observasi dan wawancara tersebut kemudian diolah dengan menggunakan metode Social Return on Investment (SROI) untuk mengukur tingkat efektivitas kegiatan CSR dalam nilai mata uang rupiah.

\section{Research State of The Art}

Konseptualisasi CSR: Konsep CSR kini telah banyak berkembang dari yang awalnya hanya menganggap CSR sebagai kegiatan sampingan, yang merupakan kewajiban perusahaan untuk menyisihkan sebagian profitnya untuk meminimalkan dampak sosial lingkungan yang terjadi. CSR berakar dari konsep yang menyatakan bahwa perusahaan memiliki kewajiban terhadap masyarakat di samping untuk mencari keuntungan bagi perusahaan semata (Godfrey \& Hatch, 2007). Konsep tersebut berkaitan erat pula dengan teori stakeholder (Ranängen, 2017), yakni teori manajemen organisasi yang memandang perusahaan bertanggung jawab terhadap beberapa konstituen.

Konsep CSR kontemporer yang lebih dominan kini mengarah pada konsep yang menyatakan bahwa perusahaan secara sukarela mengintegrasikan kepedulian sosial dan lingkungan dalam operasi bisnisnya yang melibatkan interaksi dengan berbagai stakeholder (Branco \& Rodrigues, 2006). CSR kini menjadi program yang penting untuk membangun dan mempertahankan momentum bisnis perusahaan. Program CSR merupakan kegiatan penting bagi keberlanjutan bisnis dan nilai brand perusahaan dalam jangka panjang (Middlemiss, 2003). Program CSR yang baik dapat pula menjadi sumber keunggulan kompetitif perusahaan untuk memenangkan persaingan (Piercy \& Lane, 2009). Lebih lanjut Cahya (2014) menyebutkan bahwa CSR adalah respon entitas bisnis untuk mengelola resiko dan menaikkan daya saing yang mengarah pada keberlanjutan usahanya.

Perubahan konseptualisasi tersebut mendorong CSR menjadi kegiatan yang cukup penting dalam operasi bisnis perusahaan. Selain sebagai salah satu strategi perusahaan, CSR dapat dianggap sebagai investasi sosial. Seperti halnya dengan investasi lainnya, sebagai investasi sosial perusahaan sebaiknya lebih mengalokasikan sumber dayanya untuk program CSR jangka panjang yang memiliki dampak yang signifikan (Jalal \&
Kurniawan, 2013). Dengan demikian, pelaksanaan program CSR perlu dievaluasi dari segi dampak positif yang ditimbulkan, untuk mengetahui apakah investasi sosial yang dilakukan perusahaan membawa manfaat yang signifikan atau tidak. Bentuk evaluasinya tentu akan berbeda dengan laporan tahunan dan keuangan yang selama ini dilakukan oleh perusahaan.

Evaluasi Kegiatan CSR: Untuk melihat tingkat efektivitas pelaksanaan program maka harus dilihat berdasarkan indikator-indikator yang dapat menggambarkan efektivitas dari program tersebut. Indikator tersebut adalah input, output, outcome, dan benefit impact sebagai komponen dasar sistem pengukuran kinerja (Mahmudi, 2005). Selain itu ada tiga pendekatan yang juga dapat digunakan sebagai kriteria untuk mengukur efektivitas suatu organisasi seperti yang dikemukakan oleh Lubis dan Huseini (1987), yaitu: (1) pendekatan sumber daya (resource aproach) yakni mengukur efektivitas dari input, (2) pendekatan proses (process aproach) adalah untuk melihat sejauh mana efektivits pelaksanaan program dari semua kegiatan proses internal atau mekanisme organisasi, dan (3) pendekatan sasaran (goals aproach) dimana pusat objek penelitian pada output, mengukur keberhasilan organisasi untuk mencapai hasil (output) yang sesuai dengan rencana. Rubin dan Babbie (2011) menyatakan bahwa pada dasarnya evaluasi program adalah mengukur efektivitas dari kegiatan yang dilakukan untuk mencapai tujuan formalnya. Pengukuran program yang baik adalah yang mengarah pada pengukuran performa berdasarkan outcome (Watson \& Whitley, 2017). Dengan demikian, untuk mengevaluasi outcome maka perlu mengukur dampak positif yang timbul dari kegiatan CSR yang telah dilakukan.

Hingga kini terdapat beberapa metode untuk pengukuran performa terutama dalam hal outcome yang dihasilkan, antara lain: (1) balanced scorecards, (2) matrik efisiensi biaya, (3) rasio finansial, (4) logic models, (5) cost-benefit analyses (CBAs), dan (6) Social Return on Investment (SROI) (Cooney \& Lynch-Cerullo, 2014). Salah satu metode yang kini cukup populer digunakan oleh organisasi non-profit di berbagai negara adalah metode SROI. Salah satu keunggulan metode ini adalah dapat digunakan untuk memperbaiki performa manajemen dalam melaksanakan berbagai program yang outcome-nya tidak terlihat secara jelas (Cooney \& LynchCerullo, 2014). Metode tersebut dapat digunakan oleh para peneliti sebagai pendekatan yang lurus untuk memproduksi penelitian non-positivistik dan terbebas dari teori administratif tradisional (Dufour, 2019). SROI dianggap sebagai alat valuasi dampak sosial yang telah berkembang dengan baik dan telah banyak digunakan di Inggris, Eropa, dan Amerika Utara (Watson \& Whitley, 2017). Hingga kini metode SROI telah digunakan untuk menilai dampak dari program sosial, seperti dampak program kesehatan dan layanan sosial 
(Hutchinson, Berndt, Gilbert-Hunt, George, \& Ratcliffe, 2018), serta dampak dari program seni bagi orang lanjut usia (Bosco, Schneider, \& Broome, 2019). Namun demikian belum banyak perusahaan swasta (profit) khususnya di Indonesia yang menggunakan metode ini secara khusus untuk mengevaluasi program CSR.

Kesenjangan dalam Literatur: Konseptualisasi mengenai CSR dan evaluasi CSR masih dalam tahap pengembangan dan belum mencapai maturasi, sehingga cukup banyak celah untuk berkontribusi kepada literatur akademis di bidang ini. Salah satu kesenjangan literatur yang ada adalah masih sangat sedikit penelitian yang menyediakan bukti empiris mengenai pengukuran CSR (khususnya menggunakan metode SROI). Terdapat satu penelitian yang dilakukan oleh Santoso, et al. (2018) yang memberikan salah satu bukti aplikasi SROI dalam pengukuran dampak CSR. Kegiatan penelitian tersebut dilakukan dengan objek salah satu pos pemberdayaan masyarakat perusahaan batu bara. SROI terbukti secara praktis dapat diaplikasikan dengan baik, namun masih perlu diperluas dan diperkuat penggunaannya secara saintifik. Maka dari itu studi yang dilakukan adalah memperkuat kemampuan pengukuran CSR menggunakan SROI yang mampu memberikan input bagi perusahaan maupun stakeholder-nya dalam menyeimbangkan antara kegiatan bisnis, sosial, dan lingkungan.

\section{Metode Penelitian}

Kajian menggunakan metode kualitatif dengan pendekatan studi kasus dan menggunakan alat analisis SROI. Pengumpulan data dilakukan dengan pengamatan dan indepth interview. Data terkumpul menjadi dasar analisis Social Return On Investment (SROI). Objek penelitian dalam studi kasus ini adalah Perusahaan Pembangkit Energi "Y" (nama perusahaan disamarkan untuk menjaga kerahasiaan) yang berlokasi di Jawa Barat. Penghitungan SROI mencakup empat tahapan, yakni: (1) mengidentifikasi ruang lingkup dan stakeholder, (2) memetakan dampak, (3) menilai dampak, dan (4) menyusun perhitungan dampak secara keseluruhan. Kemudian, hasil dari perhitungan SROI akan dijelaskan secara deskriptif. Adapun proses ilmiah pelaksanaan kajian tersaji pada Gambar 1.

Dalam penerapannya, kalkulasi SROI telah dikenal secara luas mempunyai kegunaan untuk merencanakan dan mengukur atau mengevaluasi terhadap kegiatan bisnis atau kegiatan sosial yang memiliki dampak terhadap aspek sosial, ekonomi, dan lingkungan. Perhitungan SROI dikembangkan berdasar pada prinsip-prinsip akuntansi dan analisis cost-benefit yang menghitung dampak sosial dalam unit moneter untuk mengilustrasikan penciptaan nilai yang dapat dipahami secara luas (Rotheroe \& Richards, 2007). Dengan menggunakan metode ini perusahaan dapat memonetisasi secara finansial dampak sosial lingkungan yang ditimbulkan. Secara garis besar rumus dari SROI adalah sebagai berikut: SROI $=($ Nilai Dampak Investasi)/ Investasi.

Metode SROI juga mengadopsi prinsip-prinsip perhitungan Net Present Value (NPV) untuk memperkirakan nilai dari dampak yang memiliki efek cukup lama atau dampak yang memiliki efek di masa yang akan datang. Dengan demikian dampak dari kegiatan sosial dapat diukur secara komprehensif. Perhitungan tersebut tentunya harus mempertimbangkan penurunan atau peningkatan efek dari kegiatan yang telah dilakukan. Tantangan terbesar dari implementasi metode SROI adalah penilaian dari nilai dampak yang melibatkan subjektifitas peneliti atau penilai yang dapat mempengaruhi validitas penilaian. Untuk meminimalkan hal tersebut, dilakukan triangulasi internal dalam tim peneliti. Sehingga hasil pengukuran tidak bergantung pada penilaian satu individu peneliti.

Theoritical Framework: Apabila dirunut dari literatur ilmiah terdahulu, studi pengukuran kegiatan yang berdampak bagi masyarakat dan lingkungan berawal dari dikemukakannya the Theory of Change (ToC). ToC secara sederhana dapat didefinisikan sebagai teori mengenai "bagaimana" dan "mengapa" sebuah inisiatif dapat berjalan (Weiss, 1995). Dengan menggunakan ToC, perubahan yang terjadi dapat diuraikan kedalam beberapa fase; hal ini sangat membantu untuk membangun asumsi yang kuat sebagai dasar perhitungan SROI. Proses pemetaan perubahan dimulai dengan mengidentifikasi dan mengatribusi inputinput stakeholder dengan nilai uang (Arvidson, Lyon, McKay, \& Moro, 2013). Proses selanjutnya adalah memetakan keluaran program dan mengidentifikasi dampak sosial, ekonomi, dan lingkungan yang timbul pada stakeholder yang dapat dilihat pada Gambar 2.

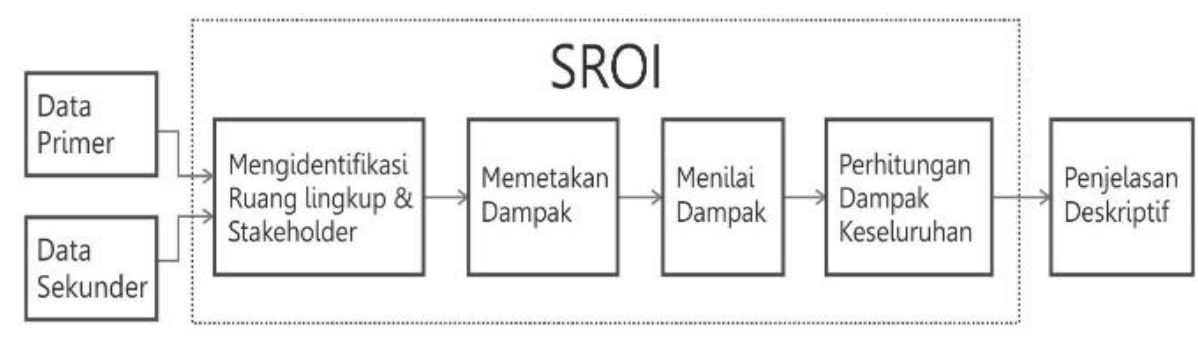

Gambar 1. Skema Proses Ilmiah Kajian 


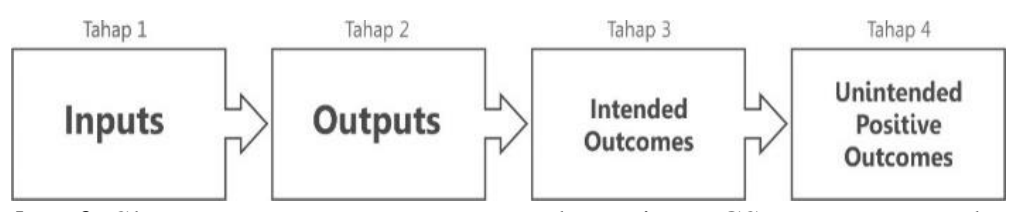

Gambar 2. Skema Proses Pemetaan Dampak Kegiatan CSR Mengacu pada TOC

Skema proses ToC memberikan petunjuk bahwa pengukuran dampak dari kegiatan sosial dan lingkungan pada program CSR harus dilakukan secara runut. Hal ini memudahkan perusahaan ntuk mengetahui aktivitas yang menimbulkan dampak signifikan dan kurang signifikan.

Mengacu pada ToC masing-masing input (uang, tenaga, dan waktu) yang dikeluarkan oleh perusahaan untuk melakukan kegiatan dengan tiap-tiap output-nya akan memiliki dampak yang berbeda (baik yang diharapkan maupun tidak). Proses pemetaan yang detail dan runut pada tiap tahapan akan mempengaruhi akurasi pengukuran pada SROI. Hasil pemetaan dan pengukuran terhadap kegiatan CSR yang dilakukan Perusahaan ' $\mathrm{Y}$ ' akan dijelaskan secara detail pada bagian hasil dan pembahasan.

\section{Hasil dan Pembahasan}

Identifikasi Ruang Lingkup dan Stakeholder:

Dalam melakukan proses identifikasi, tim peneliti melakukan cross checking antara data yang didapatkan dari Perusahaan ' $Y$ ' dengan data di lapangan. Dari proses tersebut, dapat diidentifikasi ruang lingkup kegiatan CSR Perusahaan ' $Y$ ' pada tahun 2018. Pelaksanaan kegiatan CSR Perusahaan ' $Y$ ' saat ini telah sesuai dengan UU No. 40 Tahun 2007, yang menyatakan bahwa setiap perusahaan wajib melaksanakan CSR pada area ring 1 perusahaan. Pada tahun 2018 Perusahaan ' $Y$ ' melakukan kegiatan sosial di ring 1 yang mencakup enam (6) desa di satu kabupaten di Jawa Barat. Sedangkan pada ring 2, perusahaan telah melakukan aktivitas pemberdayaan masyarakat di empat (4) desa. Adapun jangka waktu pelaksanaan kegiatan yang diamati adalah kegiatan tahun 2018, dengan mempertimbangkan dampak yang akan timbul selama dua tahun setelah pelaksanaan kegiatan CSR.

Input yang dijadikan dasar perhitungan adalah berupa realisasi belanja anggaran CSR Perusahaan ' $\mathrm{Y}$ ' sebesar Rp 795.954.000. Input keseluruhan ini kemudian dirinci untuk masing-masing kegiatan. Beberapa kegiatan tidak dimasukkan pada kajian ini karena tidak membawa perubahan yang substansial di masyarakat (contoh: pemberian sponsor untuk acara tertentu). Kemudian proses identifikasi berlanjut dengan memeriksa stakeholder penerima manfaat dari kegiatan CSR Perusahaan ' $\mathrm{Y}$ '. Lima (5) kelompok stakeholder teridentifikasi sebagai penerima manfaat dari kegiatan CSR yang telah dilaksanakan, meliputi: warga desa dewasa, komunitas, pelajar, guru pendidikan anak usia dini (PAUD), dan pemerintah daerah. Stakeholder penerima manfaat CSR dapat dilihat Tabel 1.
Pemetaan Dampak: Setelah melakukan identifikasi ruang lingkup dan stakeholder, tim peneliti melakukan pemetaan dampak yang timbul dari hasil kegiatan CSR pada masing-masing kelompok stakeholder. Dari hasil pengamatan dan wawancara mendalam, dapat diketahui output kegiatan berupa: empowerment (pemberdayaan ekonomi masyarakat), capacity building (pengembangan kapasitas sdm masyarakat), infrastruktur (pembangunan infrastruktur masyarakat), dan charity (bantuan karikatif). Dampak yang diharapkan (intended outcomes) berupa: (1) warga desa mampu mendapatkan penghasilan tambahan, (2) penghematan pemakaian gas LPG untuk memasak, (3) dapat mengurangi jumlah prevalensi terserang penyakit dan menghemat biaya pengobatan, (4) peningkatan pendapatan dan penghematan BBM dalam mengelola bank sampah, (5) memudahkan pelajar mendapatkan pekerjaan setelah lulus (tahun ke-2), (6) peningkatan pendapatan asli daerah. Dampak yang tidak diharapkan (positive unintended outcomes) berupa: (1) dapat menanggulangi kerugian kerusakan tempat tinggal akibat abrasi (dampak diperkirakan akan timbul pada tahun ke3 setelah masa penanaman), dan (2) peningkatan pendapatan PAUD. Hasil pemetaan dampak secara garis besar terrangkum dalam Tabel 2.

Penilaian Dampak: Setelah melakukan pemetaan dampak, proses pengukuran dilanjutkan dengan memberikan nilai (dalam mata uang rupiah) terhadap dampak yang kemungkinan besar akan timbul dari kegiatan CSR. Dalam proses ini, nilai proxy digunakan untuk memudahkan monetisasi dampak. Sebagian besar nilai yang digunakan sebagai proxy dibangun berdasarkan data sekunder terkini yang dikumpulkan oleh tim peneliti dan dihitung dalam jangka waktu satu tahun. Hasil penilaian dampak ditampilkan secara detail pada Tabel 3.

Perhitungan Dampak Keseluruhan: Hasil pemberian nilai pada masing-masing dampak dengan menggunakan proxy kemudian digunakan untuk menghitung keseluruhan dampak yang timbul dari program CSR. Penghitungan tersebut dilakukan dengan melakukan perkalian antara proxy dengan jumlah stakeholder terdampak Hasil perhitungan dampak keseluruhan dapat dilihat secara detail pada Tabel 4.

Penghitungan selanjutnya adalah mengurangi nilai dampak keseluruhan dengan mempertimbangkan empat aspek, yakni deadweight, displacement, attribution, dan drop-off. Hal ini dilakukan untuk mengantisipasi perubahan yang terjadi pada masyarakat dan lingkungan sekitar walaupun tanpa ada program 
Tabel 1. Stakeholder Penerima Manfaat Kegiatan CSR

\begin{tabular}{|c|c|c|c|c|}
\hline Stakeholder & Aktivitas & Rincian warga terdampak (Output) & Jumlah & $\begin{array}{c}\text { Input anggaran } \\
(\mathbf{R p})\end{array}$ \\
\hline \multirow{5}{*}{$\begin{array}{l}\text { Warga desa } \\
\text { dewasa }\end{array}$} & $\begin{array}{l}\text { Pelatihan pengolahan kotoran } \\
\text { hewan menjadi biogas \& } \\
\text { bantuan pembuatan reaktor } \\
\text { biogas }\end{array}$ & $\begin{array}{l}\text { Warga desa yang mampu mengolah kotoran hewan } \\
\text { menjadi biogas }\end{array}$ & 12 orang & 104.557 .900 \\
\hline & Pelatihan pengolahan hasil laut & $\begin{array}{l}\text { Warga desa yang mampu mengolah hasil laut } \\
\text { menjadi makanan siap jual }\end{array}$ & 6 orang & 33.128 .500 \\
\hline & Pelatihan budidaya jamur & Warga desa yang mampu budidaya jamur tiram & 6 orang & 46.476 .000 \\
\hline & $\begin{array}{l}\text { Pelatihan pembuatan kue } \\
\text { tradisional }\end{array}$ & $\begin{array}{l}\text { Warga desa yang mampu membuat kue tradisional } \\
\text { dan menjualnya }\end{array}$ & 6 orang & 14.009 .000 \\
\hline & Penanaman 1000 bibit mangrove & $\begin{array}{l}\text { Warga desa pesisir yang terselamatkan tempat } \\
\text { tinggalnya dari abrasi }\end{array}$ & 12 rumah & 50.000 .000 \\
\hline Komunitas & $\begin{array}{l}\text { Donasi kendaraan pengangkut } \\
\text { sampah beroda } 3\end{array}$ & $\begin{array}{l}\text { Komunitas Bank Sampah yang mampu menghemat } \\
\text { biaya BBM dan mampu meningkatkan } \\
\text { penghasilannya }\end{array}$ & $\begin{array}{c}1 \\
\text { komunitas }\end{array}$ & 25.000 .000 \\
\hline \multirow{4}{*}{ Pelajar } & Pelatihan kelistrikan & $\begin{array}{l}\text { Pelajar dapat mengetahui cara memproduksi listrik } \\
\text { dan pendistribusiannya ( } 10 \% \text { dari total peserta) }\end{array}$ & 48 orang & 98.637 .100 \\
\hline & $\begin{array}{l}\text { Donasi untuk kegiatan klub } \\
\text { sepak bola }\end{array}$ & $\begin{array}{l}\text { Pelajar yang termotivasi dan terlatih untuk bermain } \\
\text { sepak bola }\end{array}$ & 22 orang & 12.000 .000 \\
\hline & $\begin{array}{l}\text { Program pendidikan dasar dan } \\
\text { pelatihan bagi siswa putus } \\
\text { sekolah }\end{array}$ & $\begin{array}{l}\text { Siswa putus sekolah yang mengikuti kejar paket } \mathrm{C} \\
\text { dan mendapatkan pendidikan vokasi }\end{array}$ & 10 orang & 60.000 .000 \\
\hline & Donasi fasilitas greenhouse & $\begin{array}{l}\text { Siswa SMK dapat memahami mengenai budidaya } \\
\text { tanaman (10\% dari total peserta) }\end{array}$ & 56 orang & 30.000 .000 \\
\hline
\end{tabular}

CSR, atau perubahan terjadi atas campur tangan pihak lain (seperti pemerintah dan lembaga swadaya masyarakat). Deadweight adalah kondisi dimana perubahan sosial dan lingkungan (perubahan positif) terjadi secara alami tanpa melibatkan intervensi kegiatan CSR. Hal ini secara alami mengurangi kontribusi kegiatan CSR untuk memberikan dampak. Dalam hal ini deadweight untuk kegiatan CSR Perusahaan ' $\mathrm{Y}$ ' sebesar $10 \%$ dengan mempertimbangkan perubahan sosial yang terjadi pada masyarakat Jawa Barat yang semakin modern. Displacement terjadi dimana agen-agen yang mendapatkan intervensi atau manfaat dari kegiatan CSR di Jawa Barat berpindah ke metropolitan atau daerah lain, sehingga dampak yang timbul di Jawa Barat akan berkurang. Dalam hal ini peneliti mempertimbangkan adanya urbanisasi dan globalisasi dimana terjadi perpindahan penduduk yang cukup masif untuk mencari penghasilan yang lebih tinggi di daerah metropolitan dan/ atau luar negeri. Angka displacement dari dampak kegiatan CSR Perusahaan ' $\mathrm{Y}$ ' sebesar $15 \%$.
Attribution adalah intervensi pada masyarakat dan lingkungan yang dilakukan oleh pihak lain selain Perusahaan "Y", yang menyebabkan perubahan positif. Kontribusi pemerintah dalam pembangunan infrastruktur dan pemberdayaan masyarakat melalui penyediaan dana desa dan anggaran pembangunan mendorong terjadinya perubahan yang signifikan pada aspek sosial ekonomi masyarakat. Nilai attribution diperkirakan sebesar $18 \%$. Drop-off adalah kondisi yang terjadi secara alami dimana dampak dari kegiatan CSR berkurang dari waktu ke waktu. Melihat sebagian besar kegiatan CSR Perusahaan "Y" ditujukan untuk jangka pendek dan jangka menengah, maka nilai drop-off diperkirakan sebesar 12\%. Perhitungan terhadap nilai dampak dengan mempertimbangkan empat (4) aspek pengurang dapat dilihat pada Tabel 5.

Kemudian perhitungan dilakukan untuk jangka waktu tiga tahun untuk mengakomodasi kegiatan berdampak jangka panjang dan kegiatan yang dampaknya 
Tabel 2. Hasil Pemetaan Dampak (Outcomes) pada Stakeholder

\begin{tabular}{|c|c|c|c|}
\hline Stakeholder & $\begin{array}{c}\text { Rincian Warga } \\
\text { Terdampak (Output) }\end{array}$ & Penggalan Hasil Wawancara & $\begin{array}{c}\text { Dampak } \\
\text { (Outcomes) }\end{array}$ \\
\hline \multirow{8}{*}{$\begin{array}{l}\text { Warga desa } \\
\text { dewasa }\end{array}$} & $\begin{array}{l}\text { Warga desa yang mampu } \\
\text { membuat dan menjual batik } \\
\text { tulis }\end{array}$ & $\begin{array}{l}\text { "Batik tulis pak...mayan lah pak, saya bisa nyambi di } \\
\text { tempat bikin batik deket sini." } \\
\text { "Dari situ saya bisa bikin batik sendiri, ya ngga banyak } \\
\text { pak, seminggu paling cuma berapa gitu... trus saya titip } \\
\text { jual." }\end{array}$ & \multirow{5}{*}{$\begin{array}{l}\text { Warga desa mampu } \\
\text { mendapatkan } \\
\text { penghasilan tambahan }\end{array}$} \\
\hline & $\begin{array}{l}\text { Warga desa yang mampu } \\
\text { mendaur ulang sampah menjadi } \\
\text { barang bernilai ekonomis }\end{array}$ & $\begin{array}{l}\text { "Ya kita sama-sama disini jadi bisa bikin kerajinan, } \\
\text { kompos, macem-macem dari sampah pak, tapi ya belum } \\
\text { banyak yang beli." } \\
\text { "Ada sih pak manfaatnya, kita bisa bikin-bikin dari barang } \\
\text { rongsok, sambilan nambah duitlah dikit pak." } \\
\text { "Nyoba-nyoba pak, kalau ngga laku kan tetep bisa dijual } \\
\text { kaya bahan rongsok aja." }\end{array}$ & \\
\hline & $\begin{array}{l}\text { Warga desa yang mampu } \\
\text { membuat kue tradisional dan } \\
\text { menjualnya }\end{array}$ & $\begin{array}{l}\text { “...bisa bikin kue pak, tiga macem yang saya bisa untuk } \\
\text { jualan.” } \\
\text { “... ya jajanan pasar gitu yang terjangkau sama masyarakat } \\
\text { sini pak.” } \\
\text { "... saya jadi bisa buat untuk dititipkan ke warung pak, } \\
\text { alhamdulillah.” }\end{array}$ & \\
\hline & $\begin{array}{l}\text { Warga desa yang mampu } \\
\text { mengolah hasil laut menjadi } \\
\text { makanan siap jual }\end{array}$ & $\begin{array}{l}\text { "Bikin ikan asin, ikan asep, dibantuin kemasannya jadi } \\
\text { bisa dijual harganya bagus pak." }\end{array}$ & \\
\hline & $\begin{array}{l}\text { Warga desa yang mampu } \\
\text { budidaya jamur tiram }\end{array}$ & $\begin{array}{l}\text { "Wah kalau jamur emang cuma dikit yang bisa pak, paling } \\
\text { satu kelompok seperti kita ini yang ada pengalamannya... } \\
\text { paling cuma enem orang yang bisa sampe jualan pak." } \\
\text { "Iya lumayan terbantu, hasil kami meningkat sedikit tahun } \\
\text { ini pak." }\end{array}$ & \\
\hline & $\begin{array}{l}\text { Warga desa yang mampu } \\
\text { mengolah kotoran hewan } \\
\text { menjadi biogas }\end{array}$ & $\begin{array}{l}\text { "Alhamdulillah ada } 2 \text { RT yang dibuatin reaktor, jadi kita } \\
\text { bisa masak pake gasnya pak." } \\
\text { "Ngirit banget kalo pake gas kohe, paling iuran untuk } \\
\text { perawatan sama ngisi reaktornya." }\end{array}$ & $\begin{array}{l}\text { Penghematan } \\
\text { pemakaian gas LPG } \\
\text { untuk memasak }\end{array}$ \\
\hline & $\begin{array}{l}\text { Warga desa pesisir yang } \\
\text { terselamatkan tempat } \\
\text { tinggalnya dari abrasi }\end{array}$ & $\begin{array}{l}\text { "... sabuk ini dibikin biar rumah-rumah disitu ngga hanyut } \\
\text { pak." } \\
\text { "Nanem ini sepanjang itu pak, biar ngga kena abrasi rumah } \\
\text { warga." }\end{array}$ & $\begin{array}{l}\text { Menanggulangi } \\
\text { kerugian kerusakan } \\
\text { tempat tinggal akibat } \\
\text { abrasi }\end{array}$ \\
\hline & $\begin{array}{l}\text { Peningkatan kesehatan } \\
\text { masyarakat }\end{array}$ & $\begin{array}{l}\text { "Kalo desanya bersih sampah ngga berserakan ya kita } \\
\text { sama anak-anak jadi lebih sehat pak, ngga banyak nyamuk, } \\
\text { dan lain-lain." } \\
\text { "Itu anak-anak kalau maen ya ngga ada sampah jadi lebih } \\
\text { bersih pak, ngga gampang sakit..." }\end{array}$ & $\begin{array}{l}\text { Mengurangi jumlah } \\
\text { prevalensi terserang } \\
\text { penyakit dan } \\
\text { menghemat biaya } \\
\text { pengobatan }\end{array}$ \\
\hline Komunitas & $\begin{array}{l}\text { Komunitas Bank Sampah yang } \\
\text { mampu menghemat biaya BBM } \\
\text { dan mampu meningkatkan } \\
\text { penghasilannya }\end{array}$ & $\begin{array}{l}\text { "Kendaraan roda tiga ini praktis pak, muatnya lebih } \\
\text { banyak ngga harus bolak-balik pake motor bebek tua itu." } \\
\text { "... jadi lebih ngirit bensin setengahnya lah." }\end{array}$ & $\begin{array}{l}\text { Peningkatan } \\
\text { pendapatan komunitas }\end{array}$ \\
\hline \multirow{4}{*}{ Pelajar } & $\begin{array}{l}\text { Pelajar dapat mengetahui cara } \\
\text { memproduksi listrik dan } \\
\text { pendistribusiannya }\end{array}$ & $\begin{array}{l}\text { Dalam pelatihan peserta diberikan ujian dan diberikan } \\
\text { sertifikat. } \\
\text { "Mungkin manfaatnya nanti kalau sudah lulus bisa kerja ke } \\
\text { PT atau kontraktornya PLN gitu." }\end{array}$ & \multirow{4}{*}{$\begin{array}{l}\text { Memudahkan pelajar } \\
\text { mendapatkan } \\
\text { pekerjaan setelah lulus }\end{array}$} \\
\hline & $\begin{array}{l}\text { Pelajar yang termotivasi dan } \\
\text { terlatih untuk bermain sepak } \\
\text { bola }\end{array}$ & $\begin{array}{l}\text { "...ini ngembangin bakatnya anak-anak SD, SMP, SMA } \\
\text { sekitar sini mas biar bisa jadi atlit ntar." } \\
\text { "... kita ikut beberapa pertandingan juga mas, turnamen } \\
\text { gitu. Ntar siapa tau beberapa bisa ditarik klub mas." }\end{array}$ & \\
\hline & $\begin{array}{l}\text { Siswa putus sekolah yang } \\
\text { mengikuti kejar paket } \mathrm{C} \text { dan } \\
\text { mendapatkan pendidikan vokasi }\end{array}$ & $\begin{array}{l}\text { "... sebagai tambahan ketrampilan mas, biar bisa kerja } \\
\text { ngga ngandelin ijazah aja." }\end{array}$ & \\
\hline & $\begin{array}{l}\text { Siswa SMK dapat memahami } \\
\text { mengenai budidaya tanaman }\end{array}$ & $\begin{array}{l}\text { "Banyak manfaatnya sih kalau dikasih fasilitas gini, kita } \\
\text { bisa belajar bener-bener gimana nanem sayuran dan lain- } \\
\text { lain." }\end{array}$ & \\
\hline
\end{tabular}




\begin{tabular}{|c|c|c|c|}
\hline Stakeholder & $\begin{array}{c}\text { Rincian Warga } \\
\text { Terdampak (Output) }\end{array}$ & Penggalan Hasil Wawancara & $\begin{array}{c}\text { Dampak } \\
\text { (Outcomes) }\end{array}$ \\
\hline & & $\begin{array}{l}\text { "Saya jadi bisa nanem sayuran secara hidroponik mas... } \\
\text { nanti bisa saya bikin di rumah." }\end{array}$ & \\
\hline Guru PAUD & $\begin{array}{l}\text { Guru PAUD yang meningkat } \\
\text { kompetensinya }\end{array}$ & $\begin{array}{l}\text { "Bu guru pada tambah semangat ngajarnya, anak-anak jadi } \\
\text { lebih seneng." } \\
\text { "... saya lebih percaya pada guru-guru disini mas, bagus- } \\
\text { bagus, perhatian ke anak-anak." }\end{array}$ & $\begin{array}{l}\text { Meningkatkan kualitas } \\
\text { PAUD sehingga } \\
\text { jumlah siswa } \\
\text { bertambah (14 orang), } \\
\text { dan berdampak pada } \\
\text { peningkatan } \\
\text { pendapatan PAUD }\end{array}$ \\
\hline $\begin{array}{l}\text { Pemerintah } \\
\text { Daerah }\end{array}$ & $\begin{array}{l}\text { Peningkatan pendapatan dari } \\
\text { wahana permainan }\end{array}$ & $\begin{array}{l}\text { "Fasilitas dikasih mas, jadi bisa disewain ke pengunjung } \\
\text { yang kesini... lumayan sih." } \\
\text { "... kaya banana boat ini lumayan mas banyak yang minat } \\
\text { naik." }\end{array}$ & $\begin{array}{l}\text { Peningkatan } \\
\text { pendapatan asli daerah }\end{array}$ \\
\hline
\end{tabular}

timbul di masa yang akan datang. Perhitungan dapat dilihat pada Tabel 6. Selanjutnya suku bunga diskonto pemerintah $(5 \%)$ diperhitungkan dalam kalkulasi present value (PV) dan net present value (NPV). Setelah dilakukan penghitungan dalam jangka waktu tiga (3) tahun dan didapatkan nilai total dari dampak kegiatan CSR, maka dapat dihitung nilai SROI. Nilai total SROI dihitung sebagai berikut: SROI $=($ Rp. 2.942.113.772 Rp. 795.954.000)/ Rp. $795.954 .000=\mathbf{2 , 6 9}$.

Melihat nilai SROI terukur secara keseluruhan sebesar 2,69, maka kegiatan CSR Perusahaan ' $\mathrm{Y}$ ' dapat dikatakan cukup efektif, dimana setiap rupiah yang diinvestasikan dalam kegiatan tersebut akan menimbulkan dampak positif senilai Rp. 2,69. Namun perlu dicermati nilai dampak pada masing-masing output dan aktivitas, untuk mengetahui kegiatan apa saja yang menimbulkan dampak signifikan. Selain itu, perlu dipahami keseimbangan antara alokasi pendanaan dan keseimbangan dampak lingkungan - sosial yang ditimbulkan. Detail nilai dampak pada masing-masing aktivitas dapat dilihat pada Tabel 7.

Melihat hasil perhitungan SROI untuk masingmasing output, maka dua kegiatan CSR Perusahaan "Y" yang memiliki dampak paling signifikan adalah donasi fasilitas green house dan donasi untuk kegiatan klub sepak bola. Alokasi dan dampak positif yang ditimbulkan oleh perusahaan belum seimbang antara sosial dan lingkungan. Perusahaan "Y" lebih banyak mengalokasikan dana untuk aktivitas-aktivitas sosial bagi masyarakat di sekitar wilayah terdampak (ring 1 dan 2). Sedangkan untuk aktivitas lingkungan, perusahaan hanya melakukan satu aktivitas penanaman bibit mangrove.
Walaupun dampak yang ditimbulkan cukup baik, secara keseluruhan rasio dampak positif lingkungan sangat kecil dibandingkan dampak sosial program CSR yang telah dilakukan.

Melalui kajian evaluasi efektivitas CSR ini, dapat diketahui dampak program CSR Perusahaan Pembangkit Energy "Y" secara terinci dalam nominal rupiah. Sejalan dengan paradigma yang memandang CSR sebagai investasi (Jalal \& Kurniawan, 2013), melalui perhitungan SROI dapat diketahui dampak yang ditimbulkan dari investasi perusahaan dalam jangka waktu tiga tahun. Secara garis besar penelitian ini berkontribusi secara praktikal dengan memberikan gambaran bagi perusahaan pembangkit energi untuk dapat melakukan evaluasi program CSR menggunakan metode SROI. Evaluasi yang dilakukan tentunya dapat menjadi dasar optimasi program CSR perusahaan untuk bisa lebih menyeimbangkan antara aktivitas sosial dengan aktivitas lingkungan yang akan dilakukan.

Penelitian ini juga memberikan kontribusi teoritis dengan menghadirkan bukti empiris penggunaan metode SROI untuk evaluasi program CSR. Secara teknikal, objek penelitian dan perhitungan yang dilakukan tim peneliti sedikit berbeda dengan apa yang dilakukan oleh Santoso, et al. (2018). Di samping itu, kami menyarankan adanya modifikasi pada metode SROI khusus untuk digunakan dalam konteks evaluasi program CSR perusahaan. Sebelumnya SROI secara luas digunakan untuk melakukan valuasi dampak sosial pada lembaga non-profit (Cooney \& Lynch-Cerullo, 2014; Watson \& Whitley, 2017), sehingga perlu dilakukan penguatan atau modifikasi. Adapun modifikasi yang perlu ditambahkan 
Tabel 3. Hasil Penilaian Dampak

\begin{tabular}{|c|c|c|c|}
\hline Rincian Warga Terdampak (Output) & $\begin{array}{c}\text { Pengelompokan Berdasar Dampak } \\
\text { (Outcomes) }\end{array}$ & Proxy & $\begin{array}{l}\text { Nilai Proxy/ } \\
\text { Orang/ Tahun } \\
\text { (Rp) }\end{array}$ \\
\hline $\begin{array}{l}\text { Warga desa yang mampu membuat dan } \\
\text { menjual batik tulis }\end{array}$ & \multirow{5}{*}{$\begin{array}{l}\text { Warga desa mampu mendapatkan } \\
\text { penghasilan tambahan }\end{array}$} & \multirow{5}{*}{$\begin{array}{l}\text { Penghasilan kerja part-time } \\
\text { yang diukur dengan 50\% UMK } \\
2019(50 \% \text { x Rp } 2.117 .713)\end{array}$} & \multirow{5}{*}{12.706 .278} \\
\hline $\begin{array}{l}\text { Warga desa yang mampu mendaur ulang } \\
\text { sampah menjadi barang bernilai ekonomis }\end{array}$ & & & \\
\hline $\begin{array}{l}\text { Warga desa yang mampu membuat kue } \\
\text { tradisional dan menjualnya }\end{array}$ & & & \\
\hline $\begin{array}{l}\text { Warga desa yang mampu mengolah hasil } \\
\text { laut menjadi makanan siap jual }\end{array}$ & & & \\
\hline $\begin{array}{l}\text { Warga desa yang mampu budidaya jamur } \\
\text { tiram }\end{array}$ & & & \\
\hline $\begin{array}{l}\text { Warga desa yang mampu mengolah kotoran } \\
\text { hewan menjadi biogas }\end{array}$ & $\begin{array}{l}\text { Penghematan pemakaian gas LPG untuk } \\
\text { memasak }\end{array}$ & $\begin{array}{l}\text { Harga isi ulang } 1 \text { tabung LPG } \\
12 \mathrm{~kg} \text { untuk } 1 \text { bulan (Rp. } \\
140.000)\end{array}$ & 1.680 .000 \\
\hline $\begin{array}{l}\text { Warga desa pesisir yang terselamatkan } \\
\text { tempat tinggalnya dari abrasi }\end{array}$ & $\begin{array}{l}\text { Menanggulangi kerugian kerusakan tempat } \\
\text { tinggal akibat abrasi }\end{array}$ & $\begin{array}{l}\text { Biaya pembangunan rumah } \\
\text { RISHA Kemenpupr (Rp. } \\
50.000 .000)\end{array}$ & 50.000 .000 \\
\hline Peningkatan kesehatan masyarakat & $\begin{array}{l}\text { Mengurangi jumlah prevalensi terserang } \\
\text { penyakit dan menghemat biaya pengobatan }\end{array}$ & $\begin{array}{l}\text { Biaya pengobatan dan obat di } \\
\text { Puskesmas } \\
\text { (Rp 150.000/bulan) }\end{array}$ & 1.800 .000 \\
\hline $\begin{array}{l}\text { Komunitas Bank Sampah yang mampu } \\
\text { menghemat biaya BBM dan mampu } \\
\text { meningkatkan penghasilannya }\end{array}$ & Peningkatan pendapatan komunitas & $\begin{array}{l}\text { Estimasi pendapatan dari } \\
\text { peningkatan jumlah sampah } \\
\text { terjual dan penghematan BBM } \\
\text { (Rp. } 3.000 .000 / \text { bulan) }\end{array}$ & 36.000 .000 \\
\hline $\begin{array}{l}\text { Pelajar dapat mengetahui cara } \\
\text { memproduksi listrik dan pendistribusiannya }\end{array}$ & \multirow{4}{*}{$\begin{array}{l}\text { Memudahkan pelajar mendapatkan pekerjaan } \\
\text { setelah lulus }\end{array}$} & \multirow{4}{*}{$\begin{array}{l}\text { Penghasilan kerja full-time } \\
\text { UMK } \\
\text { (Rp. Rp 2.117.713) }\end{array}$} & \multirow{4}{*}{25.412 .556} \\
\hline $\begin{array}{l}\text { Pelajar yang termotivasi dan terlatih untuk } \\
\text { bermain sepak bola }\end{array}$ & & & \\
\hline $\begin{array}{l}\text { Siswa putus sekolah yang mengikuti kejar } \\
\text { paket } C \text { dan mendapatkan pendidikan } \\
\text { vokasi }\end{array}$ & & & \\
\hline $\begin{array}{l}\text { Siswa SMK dapat memahami mengenai } \\
\text { budidaya tanaman }\end{array}$ & & & \\
\hline $\begin{array}{l}\text { Siswa PAUD yang tertunjang proses belajar } \\
\text { dan bermainnya }\end{array}$ & $\begin{array}{l}\text { Meningkatkan kesehatan fisik dan psikis } \\
\text { anak-anak, sehingga menurunkan resiko } \\
\text { terserang penyakit dan pada akhirnya akan } \\
\text { menghemat biaya pengobatan }\end{array}$ & $\begin{array}{l}\text { Biaya pengobatan dan obat di } \\
\text { Puskesmas } \\
\text { (Rp 150.000/bulan) }\end{array}$ & 1.800 .000 \\
\hline $\begin{array}{l}\text { Guru PAUD yang meningkat } \\
\text { kompetensinya }\end{array}$ & $\begin{array}{l}\text { Meningkatkan kualitas PAUD sehingga } \\
\text { jumlah siswa bertambah ( } 14 \text { orang), dan } \\
\text { berdampak pada peningkatan pendapatan } \\
\text { PAUD }\end{array}$ & SPP PAUD (100.000/bulan) & 1.200 .000 \\
\hline $\begin{array}{l}\text { Peningkatan pendapatan dari wahana } \\
\text { permainan }\end{array}$ & Peningkatan pendapatan asli daerah & $\begin{array}{l}\text { Peningkatan pendapatan dari } \\
\text { karcis masuk dan sewa alat } \\
\text { permainan (Rp. } \\
11.000 .000 / \text { bulan) }\end{array}$ & 132.000 .000 \\
\hline
\end{tabular}

adalah: (1) pengkategorisasian aktifitas sosial dan lingkungan, dan (2) memperhitungkan dampak negatif sosial dan lingkungan sebagai pengurang dampak positif yang dihadirkan. Sehingga formula SROI menjadi sebagai berikut:

$\boldsymbol{S R O I}=\frac{((D P L-D N L)+(D P S-D N S))-\text { Investasi }}{\text { Investasi }}$

DPL merupakan dampak positif lingkungan sedangkan DNL merupakan dampak negatif lingkungan. DPS merupakan dampak positif sosial, dimana DNS merupakan dampak negatif sosial.

Formula ini menuntut perusahaan untuk lebih terbuka dan secara sadar memperhitungkan dampak negatif dalam operasi bisnisnya, sebelum melihat dampak positif dari pelaksanaan program CSR. Diperlukan upaya yang lebih cermat untuk melakukan perhitungan dengan formula ini. Oleh karena itu, diperlukan penelitian empiris lanjutan untuk dapat mengaplikasikan dan memperkuat formulasi dari hasil penelitian ini. 
Tabel 4. Penghitungan Dampak Secara Keseluruhan

\begin{tabular}{|c|c|c|c|c|}
\hline Output & Qty & Dampak (Outcomes) & $\begin{array}{l}\text { Nilai Proxy/ } \\
\text { Orang/ Tahun } \\
\text { (Rp) } \\
\end{array}$ & $\begin{array}{l}\text { Jumlah Awal } \\
\qquad(\mathbf{R p})\end{array}$ \\
\hline $\begin{array}{l}\text { Warga desa yang mampu membuat dan menjual } \\
\text { batik tulis }\end{array}$ & 10 & \multirow{4}{*}{$\begin{array}{l}\text { Warga desa mampu mendapatkan } \\
\text { penghasilan tambahan }\end{array}$} & \multirow[t]{4}{*}{$12,706,278$} & $127,062,780$ \\
\hline $\begin{array}{l}\text { Warga desa yang mampu mendaur ulang } \\
\text { sampah menjadi barang bernilai ekonomis }\end{array}$ & 15 & & & $190,594,170$ \\
\hline $\begin{array}{l}\text { Warga desa yang mampu membuat kue } \\
\text { tradisional dan menjualnya }\end{array}$ & 6 & & & $76,237,668$ \\
\hline Warga desa yang mampu budidaya jamur tiram & 6 & & & $76,237,668$ \\
\hline $\begin{array}{l}\text { Warga desa yang mampu mengolah kotoran } \\
\text { hewan menjadi biogas }\end{array}$ & 12 & $\begin{array}{l}\text { Penghematan pemakaian gas LPG untuk } \\
\text { memasak }\end{array}$ & $1,680,000$ & $20,160,000$ \\
\hline $\begin{array}{l}\text { Warga desa pesisir yang terselamatkan tempat } \\
\text { tinggalnya dari abrasi }\end{array}$ & 12 & $\begin{array}{l}\text { Menanggulangi kerugian kerusakan tempat } \\
\text { tinggal akibat abrasi }\end{array}$ & $50,000,000$ & $600,000,000$ \\
\hline $\begin{array}{l}\text { Pelajar dapat mengetahui cara memproduksi } \\
\text { listrik dan pendistribusiannya }\end{array}$ & 48 & \multirow{4}{*}{$\begin{array}{l}\text { Memudahkan pelajar mendapatkan } \\
\text { pekerjaan setelah lulus }\end{array}$} & \multirow[t]{4}{*}{$25,412,556$} & $1,219,802,688$ \\
\hline $\begin{array}{l}\text { Pelajar yang termotivasi dan terlatih untuk } \\
\text { bermain sepak bola }\end{array}$ & 22 & & & $559,076,232$ \\
\hline $\begin{array}{l}\text { Siswa putus sekolah yang mengikuti kejar paket } \\
\mathrm{C} \text { dan mendapatkan pendidikan vokasi }\end{array}$ & 10 & & & $254,125,560$ \\
\hline $\begin{array}{l}\text { Siswa SMK dapat memahami mengenai } \\
\text { budidaya tanaman }\end{array}$ & 56 & & & $1,423,103,136$ \\
\hline $\begin{array}{l}\text { Siswa PAUD yang tertunjang proses belajar dan } \\
\text { bermainnya }\end{array}$ & 72 & $\begin{array}{l}\text { Meningkatkan kesehatan fisik dan psikis } \\
\text { anak-anak, sehingga menurunkan resiko } \\
\text { terserang penyakit dan pada akhirnya akan } \\
\text { menghemat biaya pengobatan }\end{array}$ & $1,800,000$ & $129,600,000$ \\
\hline
\end{tabular}

\section{Kesimpulan}

Sangat penting bagi perusahaan pembangkit energi untuk menyeimbangkan antara operasi bisnisnya dengan aktivitas sosial dan aktivitas pelestarian lingkungan demi menjaga keberlanjutan bisnis serta kepentingan stakeholder-nya. Dalam operasionalnya, perusahaan pembangkit energi (khususnya yang menggunakan bahan bakar fosil) menghasilkan emisi yang cukup masif berupa berbagai macam polutan udara yang dapat menimbulkan dampak negatif terhadap lingkungan seperti pemanasan global dan hujan asam (Harjanto, 2008; Astra, 2010). Selain itu, terdapat dampak negatif terhadap masyarakat di sekitar fasilitas pembangkitan, yakni adanya gangguan kesehatan, gangguan kenyamanan akibat kebisingan, dan penyimpangan sosial (Astra, 2010; Prakoso, Rostyaningsih, Sundarso, \& Maron, 2016). Perusahaan tentu perlu mereduksi dampak negatif ini melalui kegiatan CSR-nya. Lebih lanjut, sebagai layaknya investasi, CSR tentu perlu dievaluasi secara mendetail untuk mengetahui apakah betul kegiatan yang dilakukan menimbulkan dampak positif yang signifikan atau tidak.

Salah satu metode yang secara global telah banyak digunakan oleh lembaga non-profit adalah metode SROI. Keunggulan metode ini adalah dapat digunakan untuk memperbaiki performa manajemen dalam melaksanakan berbagai program yang outcome-nya tidak terlihat secara jelas (Cooney \& Lynch-Cerullo, 2014). SROI dianggap sebagai alat valuasi dampak sosial yang telah berkembang dengan baik dan telah banyak digunakan di Inggris, Eropa, dan Amerika Utara (Watson \& Whitley, 2017). Namun demikian belum banyak penelitian empiris yang dilakukan untuk memberikan bukti implementasi metode SROI (khususnya di Indonesia) untuk mengevaluasi program CSR.

Penelitian ini memberikan kontribusi praktikal dengan menyediakan gambaran bagi perusahaan pembangkit energi untuk dapat mengevaluasi program CSR menggunakan metode SROI. Hasil evaluasi dapat menjadi dasar optimasi program CSR perusahaan. Hasil 
Tabel 5. Penghitungan dengan Memperhitungkan 4 Aspek Pengurang Dampak

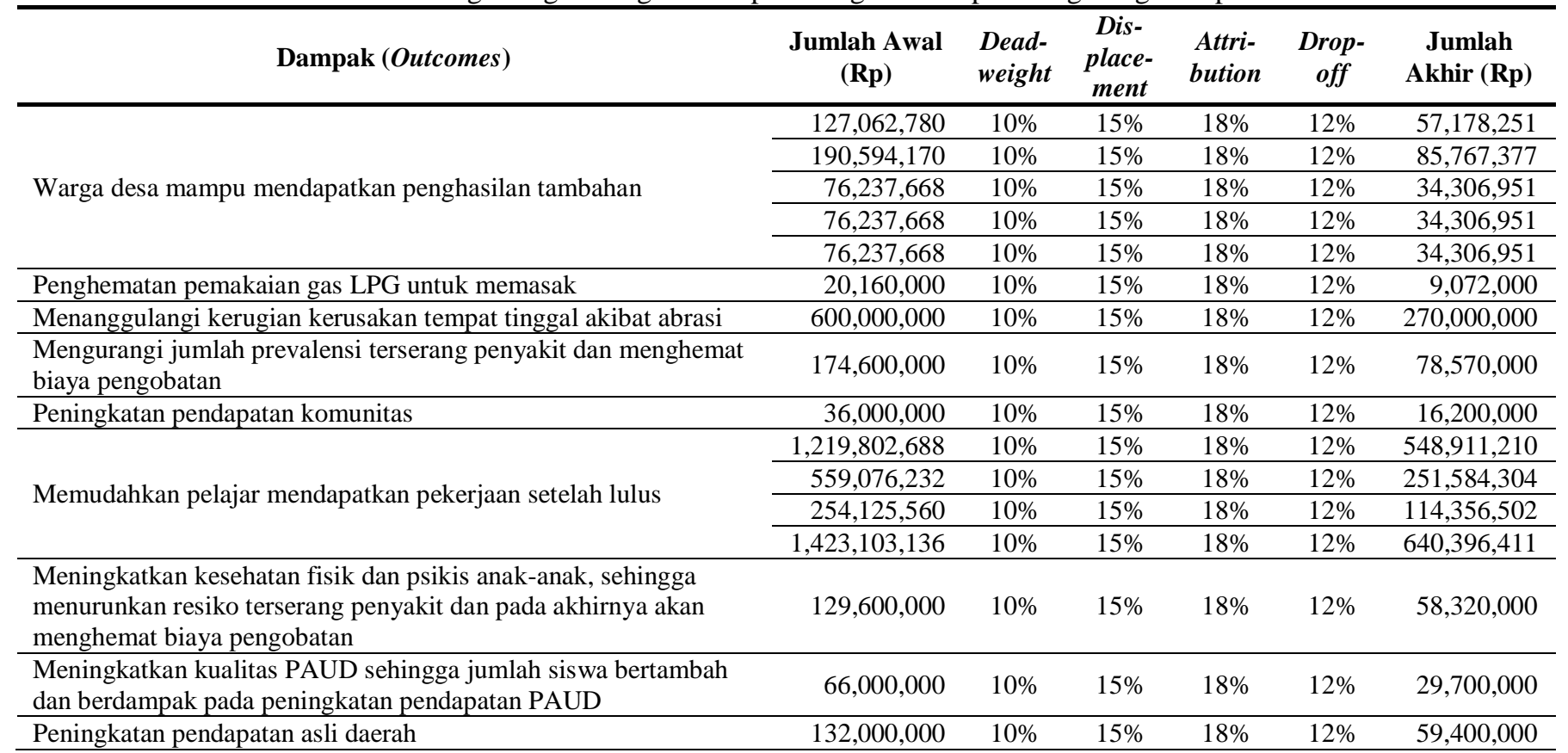

Tabel 6. Penghitungan Dampak dalam Jangka Waktu 3 Tahun

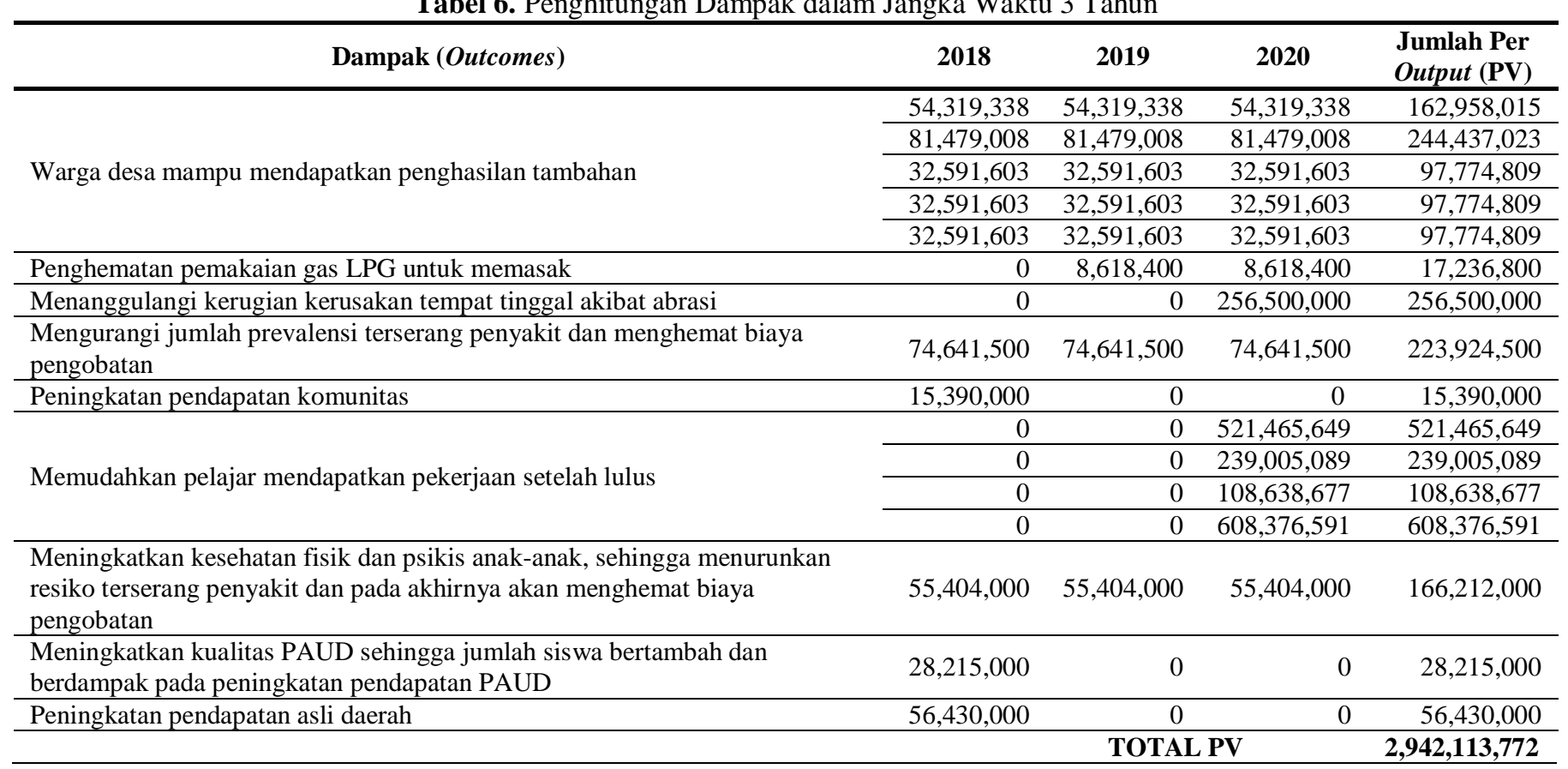

perhitungan SROI program CSR Perusahaan "Y" menunjukkan bahwa kegiatan yang dilakukan cukup efektif dengan total dampak positif yang ditimbulkan dalam kurun waktu tiga tahun sebesar Rp. 2,69 untuk tiap rupiah yang diinvestasikan dalam program CSR. Namun, Perusahaan "Y" cenderung lebih banyak melakukan aktivitas yang memberikan dampak sosial dan minim aktivitas yang berdampak positif terhadap lingkungan. Jika ditelaah secara kontekstual, seharusnya program
CSR perusahaan pembangkit energi dapat menghadirkan dampak positif terhadap lingkungan yang lebih besar dibandingkan dampak sosial, karena dampak negatif emisi menimbulkan degradasi lingkungan yang sangat masif. Jika memperhatikan keseimbangan, maka dampak positif lingkungan dari program CSR akan dapat mereduksi atau memitigasi dampak negatif lingkungan yang telah ditimbulkan. 
Tabel 7. SROI Per Output

\begin{tabular}{|c|c|c|c|c|c|}
\hline Aktivitas & Output & $\begin{array}{l}\text { Jumlah Per } \\
\text { Output (PV) }\end{array}$ & $\begin{array}{c}\text { Investasi } \\
\text { (Input) }\end{array}$ & $\begin{array}{l}\text { SROI Per } \\
\text { Output }\end{array}$ & $\begin{array}{l}\text { Kategori } \\
\text { Dampak }\end{array}$ \\
\hline Pelatihan batik tulis & $\begin{array}{l}\text { Warga desa yang mampu membuat dan menjual } \\
\text { batik tulis }\end{array}$ & $162,958,015$ & $42,140,000$ & 2.87 & Sosial \\
\hline Pelatihan daur ulang sampah & $\begin{array}{l}\text { Warga desa yang mampu mendaur ulang } \\
\text { sampah menjadi barang bernilai ekonomis }\end{array}$ & $244,437,023$ & $70,858,000$ & 2.45 & Sosial \\
\hline $\begin{array}{l}\text { Pelatihan pembuatan kue } \\
\text { tradisional }\end{array}$ & $\begin{array}{l}\text { Warga desa yang mampu membuat kue } \\
\text { tradisional dan menjualnya }\end{array}$ & $97,774,809$ & $104,557,900$ & 0.06 & Sosial \\
\hline Pelatihan pengolahan hasil laut & $\begin{array}{l}\text { Warga desa yang mampu mengolah hasil laut } \\
\text { menjadi makanan siap jual }\end{array}$ & $97,774,809$ & $33,128,500$ & 1.95 & Sosial \\
\hline Pelatihan budidaya jamur & Warga desa yang mampu budidaya jamur tiram & $97,774,809$ & $46,476,000$ & 1.10 & Sosial \\
\hline $\begin{array}{l}\text { Pelatihan pengolahan kotoran } \\
\text { hewan menjadi biogas \& } \\
\text { pembuatan reaktor biogas }\end{array}$ & $\begin{array}{l}\text { Warga desa yang mampu mengolah kotoran } \\
\text { hewan menjadi biogas }\end{array}$ & $17,236,800$ & $14,009,000$ & 0.23 & Sosial \\
\hline $\begin{array}{l}\text { Pemberdayaan masyarakat dalam } \\
\text { kegiatan kebersihan dan } \\
\text { penyelamatan lingkungan }\end{array}$ & Peningkatan kesehatan masyarakat & $223,924,500$ & $50,000,000$ & 3.48 & Sosial \\
\hline $\begin{array}{l}\text { Donasi kendaraan pengangkut } \\
\text { sampah beroda } 3\end{array}$ & $\begin{array}{l}\text { Komunitas Bank Sampah yang mampu } \\
\text { menghemat biaya BBM dan mampu } \\
\text { meningkatkan penghasilannya }\end{array}$ & $15,390,000$ & $25,000,000$ & 0.38 & Sosial \\
\hline Pelatihan kelistrikan & $\begin{array}{l}\text { Pelajar dapat mengetahui cara memproduksi } \\
\text { listrik dan pendistribusiannya }\end{array}$ & $521,465,649$ & $98,637,100$ & 4.29 & Sosial \\
\hline $\begin{array}{l}\text { Donasi untuk kegiatan klub sepak } \\
\text { bola }\end{array}$ & $\begin{array}{l}\text { Pelajar yang termotivasi dan terlatih untuk } \\
\text { bermain sepak bola }\end{array}$ & $239,005,089$ & $12,000,000$ & 18.92 & Sosial \\
\hline $\begin{array}{l}\text { Program pendidikan dasar dan } \\
\text { pelatihan bagi siswa putus sekolah }\end{array}$ & $\begin{array}{l}\text { Siswa putus sekolah yang mengikuti kejar } \\
\text { paket } \mathrm{C} \text { dan mendapatkan pendidikan vokasi }\end{array}$ & $108,638,677$ & $60,000,000$ & 0.81 & Sosial \\
\hline Donasi fasilitas greenhouse & $\begin{array}{l}\text { Siswa SMK dapat memahami mengenai } \\
\text { budidaya tanaman }\end{array}$ & $608,376,591$ & $30,000,000$ & 19.28 & Sosial \\
\hline $\begin{array}{l}\text { Donasi fasilitas belajar mengajar } \\
\text { dan alat bermain }\end{array}$ & $\begin{array}{l}\text { Siswa PAUD yang tertunjang proses belajar } \\
\text { dan bermainnya }\end{array}$ & $166,212,000$ & $155,000,000$ & 0.07 & Sosial \\
\hline Capacity building & Guru PAUD yang meningkat kompetensinya & $28,215,000$ & $15,000,000$ & 0.88 & Sosial \\
\hline $\begin{array}{l}\text { Donasi peralatan permainan di } \\
\text { daerah wisata pantai }\end{array}$ & $\begin{array}{l}\text { Peningkatan pendapatan dari wahana } \\
\text { permainan }\end{array}$ & $56,430,000$ & $50,000,000$ & 0.13 & Sosial \\
\hline Penanaman 1000 bibit mangrove & $\begin{array}{l}\text { Warga desa pesisir yang terselamatkan tempat } \\
\text { tinggalnya dari abrasi }\end{array}$ & $256,500,000$ & $50,000,000$ & 4.13 & Lingkungan \\
\hline
\end{tabular}

Penelitian ini juga memberikan kontribusi teoritis dengan menyediakan bukti empiris implementatif dan penambahan pada metode SROI untuk evaluasi program CSR. Modifikasi kecil dapat diimbuhkan pada metode SROI khusus yakni dengan mengkategorisasian aktifitas sosial dan aktifitas lingkungan, serta memperhitungkan dampak negatif sosial dan lingkungan sebagai pengurang dampak positif yang dihadirkan. Namun, karena keterbatasan waktu dan pendanaan penelitian kami belum dapat menghadirkan bukti dampak negatif pengurang dari dampak positif CSR. Untuk itu ke depannya diperlukan penelitian lebih lanjut dengan mengambil data yang lebih lengkap mencakup data dampak negatif dan positif pada daerah sekitar perusahaan energi.

\section{Daftar Pustaka}

Arvidson, M., Lyon, F., McKay, S., \& Moro, D. (2013). Valuing the social? The nature and controversies of measuring social return on investment (SROI). Voluntary Sector Review, 4(1), 3-18.
Astra, I. (2010). Energi dan dampaknya terhadap lingkungan. Jurnal Meteorologi dan geofisika, 2, 127-135.

Baron, D. (2001). Private politics, corporate social responsibility and integrated strategy. Journal of Economics and Management Strategy, 10, 7-45.

Bosco, A., Schneider, J., \& Broome, E. (2019). The social value of the arts for care home residents in England: A social return on investment (SROI) analysis of the imagine arts programme. Maturitas, 124, 15-24.

Branco, M., \& Rodrigues, L. (2006). Corporate social responsibility and resource-basedperspectives. Journal of Business Ethics, 69, 111-132.

Cahya, B. (2014). Transformasi konsep corporate social responsibility (CSR). Iqtishadia, 7(2), 203-222.

Cooney, K., \& Lynch-Cerullo, K. (2014). Measuring the social returns of nonprofits and social enterprises: The promise and perils of the SROI. Nonprofit Policy Forum 2014 (pp. 367-393). De Gruyter.

Donaldson, T., \& Preston, L. (1995). The stakeholder theory of the corporation: concepts, evidence, and 
implications. Academy of Management Review, 20, 65-91.

Dufour, B. (2019). Social impact measurement: What can impact investment practices and the policy evaluation paradigm learn from each other? Research in International Business and Finance, 47(C), 18-30.

Godfrey, P., \& Hatch, N. (2007). Researching corporate socail responsibility: An agenda for the 21st century. Journal of Business Ethics, 70, 87-98.

Harjanto, N. (2008). Dampak lingkungan pusat listrik tenaga fosil dan prospek PLTN sebagai sumber energi listrik nasional. Majalah Pengelolaan Instalasi Nuklir, 1(1), 39-50.

Hutchinson, C., Berndt, A., Gilbert-Hunt, S., George, S., \& Ratcliffe, J. (2018). Valuing the impact of health and social care programmes using social return on investment analysis: How have academics advanced the methodology? A protocol for a systematic review of peer-reviewed literature. $B M J, 1-5$.

Jalal, \& Kurniawan, F. (2013). Investasi sosial: Perspektif CSR strategis untuk pengembangan masyarakat oleh perusahaan. Social Investment Indonesia.

Lubis, S., \& Huseini, M. (1987). Teori organisasi (suatu pendekatan makro). Jakarta: Pusat Antar Universitas Ilmu-ilmu Sosial UI.

Mahmudi. (2005). Manajemen kinerja sektor publik. Yogyakarta: Unit Penerbit dan Percetakan Sekolah Tinggi Ilmu Manajemen YKPN.

McWilliams, A., \& Siegel, D. (2001). Corporate social responsibility: A theory of the firm perspective . Academy of Management Review, 26, 117-127.

McWilliams, A., Siegel, D., \& Wright, P. (2006). Corporate social responsibility: Strategic implications. Journal of Management Studies, 43(1), 1-18.
Middlemiss, N. (2003). Authentic not cosmetic: CSR as brand enhancement. Journal of Brand Management, 10(4-5), 353-361.

Piercy, N., \& Lane, N. (2009). Corporate social responsibility: Impacts on strategic marketing and customer value. The Marketing Review, 8(4), 335360.

Prakoso, B., Rostyaningsih, D., Sundarso, \& Maron, A. (2016). Evaluasi dampak pembangunan pembangkit listrik tenaga uap (PLTU) tanjung jati di desa tubanan kecamatan kembang kabupaten jepara. Journal of Public Policy and Management Review, 208-222.

Ranängen, H. (2017). Stakeholder management theory meets CSR practice in Swedish mining. Miner Economics, 30, 15-29.

Rotheroe, N., \& Richards, A. (2007). Social return on investment and social enterprise: Transparent accountability for sustainable development. Social Enterprise Journal, 3(1), 31-48.

Santoso, M., Adinegara, R., Ismanto, S., Mumajad, I., \& Mulyono, H. (2018). Penilaian dampak investasi sosial pelaksanaan CSR menggunakan metode social return on investment (SROI). AdBispreneur: Jurnal Pemikiran dan Penelitian Administrasi Bisnis dan Kewirausahaan, 3(2), 153-167.

Watson, K., \& Whitley, T. (2017). Applying social return on investment (SROI) to the built environment. Building Research \& Information, 46(8), 875-891.

Weiss, C. (1995). Nothing as practical as good theory: Exploring theory-based evaluation for comprehensive community initiatives for children and families. In J. e. Connell, New approaches to evaluating community initiatives: Concepts, methods, and contexts. Washington, DC: Aspen Institute.

Werner, W., \& Chandler, D. (2011). Strategic Corporate Social Responsibility. Thousand Oaks, California: Sage. 